\title{
THE ENVIRONMENTAL ASPECTS OF ENERGY CROPS GROWING IN THE CONDITION OF THE CZECH REPUBLIC
}

\author{
Marek Kopecky, Jan Moudry jr., Jaroslav Bernas, Karel Suchy \\ University of South Bohemia in Ceske Budejovice, Czech Republic \\ kopeckymarek@seznam.cz
}

\begin{abstract}
Renewable energy resources have been developing very fast due to negative effects and finite reserves of the fossil fuels. Biomass is ranked among the most promising renewable energy resources within the Central Europe. Corn (Zea mays L.) is currently the most widely grown crop in the Czech Republic; nevertheless, the cultivation of corn provokes soil erosion by water. Perennial energy grass called tall wheatgrass (Elymus elongatus subsp. Ponticus cv. Szarvasi-1) is supposed to be a good and environment-friendly alternative to corn. Field trials including these two crops were established in the experimental locality of South Bohemia. Their yield potential was monitored during spring harvest periods (use for combustion). Dry phytomass was fundamentally analysed (N, C, H, S) and higher heating value was determined too. Universal Soil Loss Equation was calculated for both crop species. Corn provided much higher average yield in a three-year interval; corn phytomass reached higher heating value as well. The area of Elymus elongatus should enlarge considerably, if we wanted to get the identical amount of energy from corn and Elymus elongatus. However, we found that, compared to Zea mays L., water erosion theoretical land losses would be several times less serious for Elymus elongatus.
\end{abstract}

Key words: energy crops, erosion, yield.

\section{Introduction}

Fast world population growth (Schau \& Fet, 2008) provokes a higher demand for energy (Ho \& Show, 2015). A considerable demand for energy is met by fossil fuels (Sakuragi, Kuroda, \& Ueda, 2011). Burning of fossil fuels pollutes the environment (Nicoletti et al., 2015) and produces greenhouse gas emissions (Moutinho, Madaleno, \& Silva, 2016). Global reserves of fossil fuels are strictly limited. Therefore, renewable energy resources (RER) have become a key issue to be raised (Bernas et al., 2014). RER may help change the climate (Cherubini \& Strømman, 2011).

Biomass is one of the most significant RER (Bernas et al., 2016b). It is used for direct combustion or biogas production (Jasinskas, Zaltauskas, \& Kryzeviciene, 2008). Demirbas (2004) considers the near future promising - biomass can be burnt. Low water content in biomass is crucial. Therefore, the right harvest time is necessary and important there. It also determines a proportion and composition of chemical elements in phytomass. If we harvest plants later, the proportion of unwanted chemical elements decreases $(\mathrm{N}, \mathrm{S}$, $\mathrm{K}, \mathrm{Na}$ and $\mathrm{Cl}$ are not good for burning, they slow it down) (Hadders \& Olsson, 1996). The amount of ash which is produced by biomass burning is important. Csete et al. (2011) state that there is about 5\% of ash in tall wheatgrass (Elymus elongatus subsp. ponticus cv. Szarvasi-1). Almost the same percentage of ash is indicated in corn (Zea mays L.) straw (Durda et al., 2016).

Energy crops have become more popular and the area of energy crops has been extending in the Czech Republic (Kopecky et al., 2015). Nowadays, corn is very popular there(Mast et al., 2014). It is, nevertheless, considered an environmentally unfriendly crop (Vogel, Deumlich, \& Kaupenjohann, 2016). It contaminates ground water with nitrates (Glavan, Zorcic, \& Pintar, 2016). There is a competition between energy crops and food production as well (Emmann, Schaper, $\&$ Theuvsen, 2012). A high risk of water erosion is another negative aspect of corn growing (Vogel, Deumlich, \& Kaupenjohann, 2016). Soil erosion is a common problem that complicates watershed management around the world (Karas, 2016).

As the erosion damages the upper and most fertile soil layer the most, it causes the production and nonproduction potential of the soil to decrease (BlancoCanqui \& Lal, 2008). There are specific conditions for water erosion in the Czech Republic - because of the area of land blocs; they are the largest land blocs amongst all the European countries. Former land management system caused many hydrographical or landscape features to be removed from the countryside; such features, nevertheless, protected the soil against erosion very well. Nowadays, more than one half of arable land is endangered by water erosion in the Czech Republic (Novotny et al., 2014).

Grasslands and grass growing seem to be environment-friendly measures; they provide a sufficient amount of phytomass which is used in the eco energy sector (Kopecky et al., 2017). Compared to an annual crop, perennial grass protects the land against torrential rains and wind more and all year long (Mrkvicka, Vesela, \& Ninaj, 2007). Therefore, it is highly recommended to grow grass in regions and localities facing water erosion (Dumbrovsky et al., 2014). Growth is the only arable land management factor we can influence directly - it is important to adopt anti-erosion measures at the same time in order 
Table 1

Annual and seasonal climate of the years 2013 - 2015 at the experimental site of České Budejovice

\begin{tabular}{|l|c|c|c|c|}
\hline \multicolumn{1}{|c|}{ Year } & \multicolumn{2}{c|}{ Average temperature $\left({ }^{\circ} \mathrm{C}\right)$} & \multicolumn{2}{c|}{ Precipitation $(\mathrm{mm})$} \\
\hline & year & season & year & season \\
\hline 2013 & 9.1 & 15.3 & 685.4 & 469.5 \\
\hline 2014 & 10.2 & 15.1 & 595.9 & 428.7 \\
\hline 2015 & 10.5 & 16.9 & 487.7 & 233.8 \\
\hline Long-term average (1961-1990) & 8.3 & 14.2 & 520.0 & 366.2 \\
\hline
\end{tabular}

Habitat characteristics

Table 2

\begin{tabular}{|l|l|}
\hline Altitude (MSL) & 400 \\
\hline Agricultural production region & grain-growing \\
\hline Soil texture class & medium heavy-textured soil \\
\hline Soil type & pseudogley cambisoil \\
\hline $\mathrm{pH} \mathrm{H} \mathrm{O}$ & 6.1 \\
\hline $\mathrm{pH} \mathrm{KCl}$ & 5.6 \\
\hline GPS coordinates & $48^{\circ} 97^{\prime} 44.13^{\prime \prime} \mathrm{N}, 14^{\circ} 44^{\prime} 88.37^{\prime}{ }^{\prime} \mathrm{E}$ \\
\hline
\end{tabular}

to protect the land against erosion (Novotny et al., 2014). Grasslands play an important ecological and environmental role in the landscape (Nitsch et al., 2012). Compared to annual crops, they require fewer fertilizers (Lewandowski et al., 2003).

Bernas et al. (2016a) also consider Phalaris arundinacea L. and Elymus elongatus to be suitable energy grass species. Csete et al. (2011) recommend Elymus elongatus subsp. ponticus cv. Szarvasi-1 too; they highly appreciate its yield potential and droughtresistance properties. Water deficiency is supposed to be the major agricultural threat (Konvalina et al., 2014).

This article intends to compare the conventionally grown corn and the alternative tall wheatgrass from the point of view of their yield potential and energy gain. It also intends to determine water erosion threat the soil faces - crop stands of these energy crops were monitored at the experimental locality of the University of South Bohemia in České Budějovice. The trial was conducted between 2013 and 2016.

\section{Materials and Methods}

Small-plot trials with Elymus elongatus subsp. ponticus (cv. Szarvasi-1) and Zea mays L. (hybrid Simao) were established in South Bohemia, at an experimental station of the University of South Bohemia in České Budějovice. Characteristics of the test habitats are described in Tables 1 and 2.

The experimental plot had been fertilized with mineral fertilizers before perennial grass of Elymus elongatus was seeded there. The following amounts of fertilizer were used: $200 \mathrm{~kg}$ of ammonium sulphate per hectare, $100 \mathrm{~kg}$ of ammonium nitrate with dolomite per hectare, $300 \mathrm{~kg}$ of triple superphosphate per hectare and $60 \mathrm{~kg}$ of potassium chloride per hectare. Grass was seeded on the experimental plot on 17 April 2013. Four small experimental plots were established there - each of them having an area of 10 square metres ( 8 times $1.25 \mathrm{~m}$ ). The phytomass was harvested every spring of 2014, 2015 and 2016 (on 1 April 2014, on 17 March 2015 and on 21 March 2016) - the phytomass plants contained little water then. The harvest of 2014 represents the yield for 2013 growing season, and so on. The crop stands were cut with a grass mower having a mowing bar. They were left $6 \mathrm{~cm}$ long. After mowing the crop stand, mineral fertilizers were applied $-300 \mathrm{~kg}$ of ammonium sulphate per hectare, $150 \mathrm{~kg}$ of ammonium nitrate with dolomite per hectare, $60 \mathrm{~kg}$ of triple superphosphate per hectare and $60 \mathrm{~kg}$ of potassium chloride per hectare.

Corn crop stand (an area of 100 square meters) was established every spring of 2013, 2014 and 2015 (17 May 2013, 15 May 2014 and 17 April 2015). After the crop stand was seeded, fertilizers were applied there $-220 \mathrm{~kg}$ of ureastabil per hectare, 190 $\mathrm{kg}$ of triple superphosphate per hectare and $100 \mathrm{~kg}$ of potassium chloride. Another $115 \mathrm{~kg}$ of ureastabil per hectare were added into the crop stand during the stage of growth. Zea mays L. was harvested in the same period of time as Elymus elongatus.

Afterwards, the harvested fresh matter yield was determined and processed for drying. Dry matter (DM) content was determined by drying the biomass at $60{ }^{\circ} \mathrm{C}$ until constant weight. Based on water content, 
the yield of the fresh matter was converted to the dry matter hectare yield.

Dried samples of both plants were homogenized and they were subjected to the elementary analysis in the Central Laboratories of the Czech Technical University in Prague. Elementary elements (N, C, H, and S) were detected in the phytomass with the Vario EL CUBE equipment, which is based on a purge\&trap chromatography and separates gasses emerging from a sample burning; it provides the maximum working extent possible - greater extent than the other analyzers provide. Then percentage of oxygen was calculated $(\mathrm{O}=100-\mathrm{N}-\mathrm{C}-\mathrm{H}-\mathrm{S}-\mathrm{ash})$; in this equation, ash was replaced by a common figure of $5 \%$ which is very often mentioned in special literature sources. Higher heating value (HHV) was calculated afterwards. A pattern recommended by Sheng \& Azvedo (2005) was used there (Sheng \& Azvedo considered the pattern the most exact):

$$
\begin{aligned}
H H V= & -1.3675+0.3137 \times C+0.7009 \\
& \times H+0.0318 \times O\left(M J \cdot \mathrm{kg}^{-1}\right)
\end{aligned}
$$

HHV ... higher heating value

$\mathrm{C}, \mathrm{O}, \mathrm{H} \ldots$ weight percentage of elements in a dry sample

Based on the data acquired, energy gain was calculated for both crops afterwards.

$$
E=H H V \times Y\left(G J \cdot h a^{-1}\right)
$$

E... energy gain

HHV ... higher heating value

$\mathrm{Y}$... average yield of DM

A long-time loss of the soil caused by water erosion was also calculated via Universal Soil Loss Equation (Wischmeier \& Smith, 1978):

$$
\begin{aligned}
G= & R \times K \times L \times S \times C \times \\
& \times P\left(t \cdot h a^{-1} \cdot \text { year }^{-1}\right)
\end{aligned}
$$

G... the computed soil loss per unit area, expressed in the units selected for $\mathrm{K}$ and for the period selected for $\mathrm{R}$

$\mathrm{R}$... the rainfall and runoff factor
K... the soil erodibility factor

L... the slope-length factor

S... the slope-steepness factor

C... the cover and management factor

P... the support practice factor

We used a substitution and substituted R-factor with 40 which was recommended for the region of the Czech Republic. Other factors were derived from relevant plants and calculated for every single experimental plot (local geographical and land conditions). K-factor of 0.38 and S-factor of 0.47 were the same for both crops. Zea mays L. reached the $\mathrm{L}$-factor of 1.62 and $\mathrm{C}$-factor of 0.32. Elymus elongates reached the L-factor of 1.35 and $\mathrm{C}$-factor of 0.005 . We used another substitution and substituted P-factor with 1 in the equation (no anti-erosion measures). Figures of the factors had been derived from Janecek et al. (2012) and their methodology. Multiplying G-value by an area generating $1 \mathrm{TJ}$ of energy, we got the total amount of soil theoretically washed away by the water erosion (if we grow the above-mentioned and assessed energy crops).

\section{Results and Discussion}

Yield produced by grass and corn between 2014 and 2016 is shown in Figure 1. As far as Elymus elongatus is concerned, there is an average of four micro plots. In 2014, Elymus elongatus produced a low yield which was caused by slow growth in the initial stage of growth. On the other hand, in 2015 (harvest in 2016), its great potential for growth and yield potential showed. In spite of the extreme weather conditions - long dry periods that could even reduce yield to its one half (Csete et al., 2011), this grass species produced the yield of $9.6 \mathrm{t} \cdot \mathrm{ha}^{-1} \mathrm{DM}$. On the other hand, Zea mays L. could not cope with the atypical weather conditions and it produced very low yield.

Zea mays L. reached the 2014/2016 average yield of $12.7 \mathrm{t} \cdot \mathrm{ha}^{-1}$ of DM and Elymus elongatus reached the 2014/2016 average yield of $7.1 \mathrm{t} \cdot \mathrm{ha}^{-1}$ of DM. Compared to available data, corn and grass reached yield figures are relatively low. For example, Mast et al. (2014) show Elymus elongatus yield of $8.9 \mathrm{t} \cdot \mathrm{ha}^{-1}-$ $13.4 \mathrm{t} \cdot \mathrm{ha}^{-1} \mathrm{DM}$ (they largely depend on harvest time). Other authors show Elymus elongatus yield of up to $20 \mathrm{t} \cdot \mathrm{ha}^{-1} \mathrm{DM}$. Zea mays L. did not produce any high

\section{Elementary analysis}

\begin{tabular}{|l|c|c|c|c|}
\hline Plant species & $\% \mathrm{~N}$ & $\mathrm{C} \%$ & $\mathrm{H} \%$ & $\mathrm{~S} \%$ \\
\hline Zea mays L. & 1.238 & 43.37 & 7.04 & 0.07 \\
\hline Elymus elongatus & 0.64 & 43.73 & 6.29 & 0.07 \\
\hline
\end{tabular}




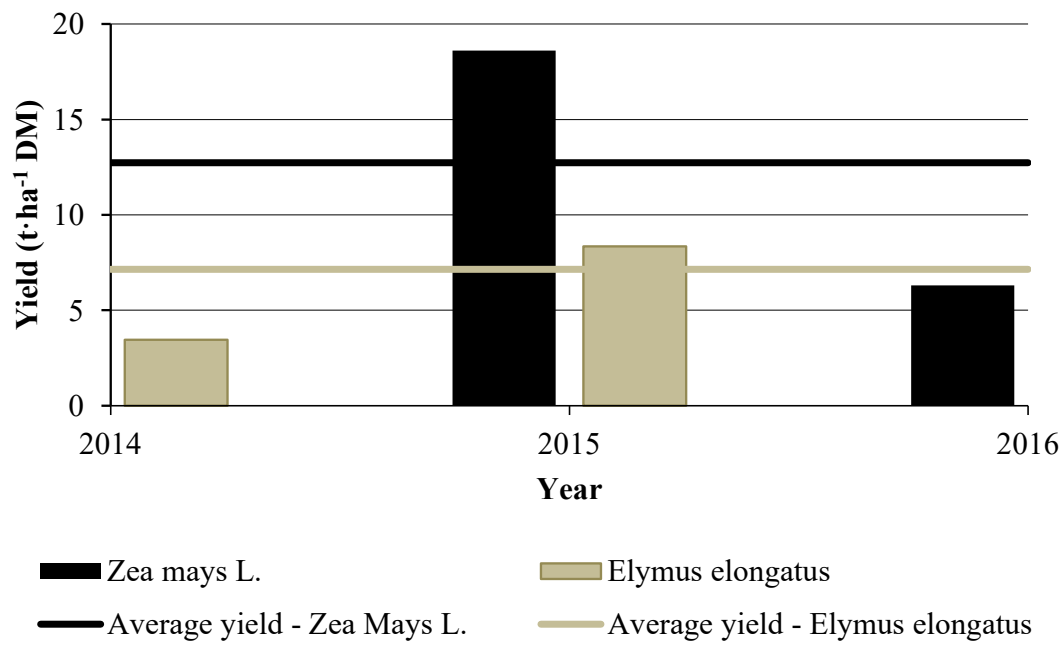

Figure 1. Yield of energy crops.

yield at the same station either $\left(12.7 \mathrm{t} \cdot \mathrm{ha}^{-1} \mathrm{DM}\right)$. For example, Badalikova, \& Bartlova (2011) showed the yield of $20.26 \mathrm{t} \cdot \mathrm{ha}^{-1} \mathrm{DM}$ (usual farming technology, ploughing).

Based on the elementary analysis results (Table 3), $\mathrm{HHV}$ was calculated for both crops. Zea mays L. reached the figure of $18.6 \mathrm{MJ} \cdot \mathrm{kg}^{-1}$ and Elymus elongatus reached the figure of $18.2 \mathrm{MJ} \cdot \mathrm{kg}^{-1}$. Such figures correspond to commonly accepted figures. For example, Demirbas (2001) states the figure of 18.27 $\mathrm{MJ} \cdot \mathrm{kg}^{-1}$ for corn straw.

Zea mays L. crop stand reached the average energy gain figure of $236.2 \mathrm{GJ} \cdot \mathrm{ha}^{-1}$ and Elymus elongates crop stand reached the average energy gain figure of 129.8 $\mathrm{GJ} \mathrm{ha}^{-1}$. Re-calculating the above-mentioned figures, we found that we need 4.23 ha of Zea mays L. or 7.70 ha of Elymus elongates, so that we get $1 \mathrm{TJ}$ of energy from the phytomass. The amount of soil theoretically washed away due to water erosion is very different - it is $29.8 \mathrm{t}$ in the case of Zea mays L. cultivation and $0.4 \mathrm{t}$ in the case of Elymus elongatus cultivation. According to Vogel, Deumlich \& Kaupenjohann (2016), crop stands do not effectively protect land or the soil against water erosion. According to a lot of authors (e.g. Prochnow et al., 2009), grassland successfully protects land and soil against water erosion (much better than wide-row crops).

\section{Conclusions}

Corn produced the average yield of $12.7 \mathrm{t} \cdot \mathrm{ha}^{-1}$ DM. Tall wheatgrass produced the average yield of $7.1 \mathrm{t} \cdot \mathrm{ha}^{-1} \mathrm{DM}$. Pursuant the results of elementary analysis of phytomass samples, corn HHV attained 18.6 $\mathrm{MJ} \cdot \mathrm{kg}^{-1}$ and tall wheatgrass $\mathrm{HHV}$ attained $18.2 \mathrm{MJ} \mathrm{kg}^{-1}$. Corn produced twice as high hectare energy $\left(236.2 \mathrm{GJ} \cdot \mathrm{ha}^{-1}\right)$ yield as tall wheatgrass (129.8 $\left.\mathrm{GJ} \cdot \mathrm{ha}^{-1}\right)$. Corn area needed for $1 \mathrm{TJ}$ of energy was much larger than tall wheatgrass area. On the other hand, tall wheatgrass is an efficient method of land and soil protection against water erosion. It perfectly protects land and soil. Universal Soil Loss Equation calculation confirmed this fact as well. If we produced the amount of phytomass needed for $1 \mathrm{TJ}$ of energy on a certain parcel, only 0.4 tons of the soil would be washed away by water erosion for tall wheatgrass and 29.8 tons for corn. Perennial energy grass species are good alternatives to corn; they effectively protect land and soil against water erosion and they also provide us with other services and are ecosystem-friendly.

\section{Acknowledgements}

This work was supported by the University of South Bohemia in České Budějovice (project No. GAJU 094/2016/Z).

\section{References}

1. Badalikova, B., \& Bartlova, J. (2010). Tvorba výnosů pšenice ozimé a silážní kukuřice při různém zpracování půdy (Forming of winter wheat and silage maize yields by different soil tillage). In Rostliny v podmínkách měnícího se klimatu (Plants in a changing climate). 20 - 21 October 2011 (pp. 1 - 5). Brno, Czech Republic: Mendel University in Brno. (in Czech).

2. Bernas, J., Kopecky, M., Moudry, J. jr., Jelinkova, Z., Moudry, J., \& Suchy, K. (2016a). Cultivation of tall wheatgrass and reed canary grass for energy purposes in terms of environmental impacts. In Proceeding of 6th International Conference on Trends in Agricultural Engineering 2016. 7 - 9 September 2016 (pp. 64 - 70). Prague, Czech Republic: Czech University of Life Sciences Prague. 
3. Bernas, J., Moudry J. jr., Jelinkova, Z., Kopecky, M., Konvalina, P., \& Moudry, J. (2016b). Energy crops growing-impact on greenhouse gases emissions. Journal of Environmental Protection and Ecology. 17(3), $950-960$.

4. Bernas, J., Moudry, J. jr., Jelinkova, Z., \& Kopecky, M. (2014). Greenhouse gasses emissions during maize growing for energy purposes. In MendelNet 2014. 19 - 20 November 2014 (pp. 219 - 223). Brno, Czech Republic: Mendel University in Brno.

5. Blanco-Canqui, H., \& Lal, R. (2008). Principles of Soil Conservation and Management, Springer, DOI: 10.1007/978-1-4020-8709-7.

6. Cherubini, F., \& Strømman, A.H. (2011). Life cycle assessment of bioenergy systems: state of the art and future challenges. Bioresource technology, 102(2), 437 - 451. DOI: 10.1016/j.biortech.2010.08.010.

7. Csete, S., Stranczinger, S., Szalontai, B., Farkas, A., Pal, R.W., Salamon-Albert, E., ... Borhidi, A. (2011). Tall wheatgrass cultivar szarvasi-1 (Elymus elongatus subsp. ponticus cv. Szarvasi-1) as a potential energy crop for semi-arid lands of Eastern Europe. In Nayreripour, M., \& Kheshti, M., (Eds.), Sustainable Growth and Application in Renewable Energy Source (pp. 269 - 295). Rijeka, Croatia: INTECH Open Access Publisher.

8. Demirbaş, A. (2001). Relationships between lignin contents and heating values of biomass. Energy conversion and management, 42(2), 183 - 188. DOI: 10.1016/S0196-8904(00)00050-9.

9. Demirbas, A. (2004). Combustion characteristics of different biomass fuels. Progress in Energy and Combustion Science. 30(2), 219 - 230. DOI: 10.1016/j.pecs.2003.10.004.

10. Dumbrovsky, M., Sobotkova, V., Sarapatka, B., Chlubna, L., \& Vachalova, R. (2014). Cost-effectiveness evaluation of model design variants of broad-base terrace in soil erosion control. Ecological Engineering, 68, 260 - 269. DOI: 10.1016/j.ecoleng.2014.03.082.

11. Durda, T., Mosko, J., Pohorely, M., Svoboda, K., Zacha, B., Syc, M., Jeremias, M., Krausova, A., \& Puncochar, M. (2016). Spalování kukuřičné slámy v reaktoru s bublinovou fluidní vrstvou (Combustion of Corn Straw in a Bubbling Fluidized-Bed Reactor). Paliva (Fuels). 8(1). 29 - 38 pp. (in Czech).

12. Emmann, C.H., Schaper, C., \& Theuvsen, L. (2012). Der Markt für Bioenergie 2012 (The market for bioenergy 2012). German Journal of Agricultural Economics, 61(1), 93 - 112. (in German).

13. Glavan, M., Zorcic, P.O., \& Pintar, M. (2016). Modelling Agri-Environmental Measures for Minimizing Soil Erosion While Protecting Valuable Agricultural Land. In River Basin Management (pp. 165 - 189). Rieka, Croatia: INTECH Open Access Publisher. DOI: 10.5772/63380.

14. Hadders, G., \& Olsson, R. (1996). European Energy Crops Overview: country report for Sweden. Uppsala, Sweden: Jordbrukstekniska institutet.

15. Ho, Y.C., \& Show, K.Y. (2015). A perspective in renewable energy production from biomass pyrolysischallenges and prospects. Current Organic Chemistry, 19(5), 423 - 436. DOI: 10.2174/13852728196661 50119223318.

16. Janecek, M., Dostal, T., Kozlovsky-Dufkova, J., Dumbrovsky, M., Hula, J., Kadlec, V., ... Vlasak, J. (2012). Ochrana zemědělské půdy před erozí: Metodika (Protection of agricultural land against erosion: Methodology). Prague, Czech Republic: Czech University of Life Sciences Prague. (in Czech).

17. Jasinskas, A., Zaltauskas, A., \& Kryzeviciene, A. (2008). The investigation of growing and using of tall perennial grasses as energy crops. Biomass and Bioenergy, 32(11), 981 - 987. DOI: 10.1016/j. biombioe.2008.01.025.

18. Karas, E. (2016). Sustainable Land Use Planning Model in Rural Basins, In River Basin Management (pp. 165 - 189). Rieka, Croatia: INTECH Open Access Publisher. DOI: 10.5772/63714.

19. Konvalina, P., Moudry, J., Suchy, K., Capouchova, I., \& Janovska, D. (2014). Diversity of carbon isotope discrimination in genetic resources of wheat. Cereal Research Communications, 42(4), 687 - 699. DOI: 10.1556/CRC.2014.0002.

20. Kopecky, M., Bernas, J., Moudry, J. jr., \& Kobes, M. (2015). Germination of Selected Grass Species in Water Stress Condition. In SEED AND SEEDLINGS. XII. Scientific and technical seminar. 5. February 2015 (pp. 216 - 221). Prague, Czech Republic: Czech University of Life Sciences Prague. (in Czech).

21. Kopecky, M., Moudry, J.jr., Hloucalova, P., Bernas, J., Vachalova, R., \& Kyptova, M. (2017). Germination of seeds of selected energy grasses under water stress. In SEED AND SEEDLINGS. XIII. Scientific and technical seminar, 2. February 2017 (pp. 187 - 192). Prague, Czech Republic: Czech University of Life Sciences Prague. (in Czech).

22. Lewandowski, I., Scurlock, J.M., Lindvall, E., \& Christou, M. (2003). The development and current status of perennial rhizomatous grasses as energy crops in the US and Europe. Biomass and Bioenergy, 25(4), 335 - 361. DOI: 10.1016/S0961-9534(03)00030-8. 
23. Mast, B., Lemmer, A., Oechsner, H., Reinhardt-Hanisch, A., Claupein, W., \& Graeff-Hönninger, S. (2014). Methane yield potential of novel perennial biogas crops influenced by harvest date. Industrial Crops and Products, 58, 194 - 203. DOI: 10.1016/j.indcrop.2014.04.017.

24. Moutinho, V., Madaleno, M., \& Silva, P.M. (2016). Which factors drive CO2 emissions in EU-15? Decomposition and innovative accounting. Energy Efficiency, 9(5), 1087 - 1113. DOI: 10.1007/s12053015-9411-x.

25. Mrkvicka, J., Vesela, M., \& Ninaj, M. (2007). Permanent grassland - its function in countryside. In Organic agriculture 2007, 6 - 7 February 2007 (pp. 188 - 190). Prague, Czech Republic: Czech University of Life Sciences Prague.

26. Nicoletti, G., Arcuri, N., Nicoletti, G., \& Bruno, R. (2015). A technical and environmental comparison between hydrogen and some fossil fuels. Energy Conversion and Management, 89, 205 - 213. DOI: 10.1016/j.enconman.2014.09.057.

27. Nitsch, H., Osterburg, B., Roggendorf, W., \& Laggner, B. (2012). Cross compliance and the protection of grassland-Illustrative analyses of land use transitions between permanent grassland and arable land in German regions. Land Use Policy, 29(2), 440 - 448. DOI: 10.1016/j.landusepol.2011.09.001.

28. Novotny, I., Mistr, M., Papaj, V., Kristenova, H., Vanova, V., Kapicka, J., ... Smolkova, I. (2014). Př́ručka ochrany proti vodní erozi (Handbook of protection against water erosion). Prague, Czech Republic: Ministry of Agriculture. (in Czech).

29. Prochnow, A., Heiermann, M., Plöchl, M., Linke, B., Idler, C., Amon, T., \& Hobbs, P.J. (2009). Bioenergy from permanent grassland-A review: 1. Biogas. Bioresource technology, 100(21), 4931 - 4944. DOI: 10.1016/j.biortech.2009.05.070.

30. Sakuragi, H., Kuroda, K., \& Ueda, M. (2011). Molecular breeding of advanced microorganisms for biofuel production. Journal of Biomedicine and Biotechnology, 2011, 1 - 11. DOI: 10.1155/2011/416931.

31. Schau, E.M., \& Fet, A.M. (2008). LCA studies of food products as background for environmental product declarations. The International Journal of Life Cycle Assessment, 13(3), 255 - 264. DOI: 10.1065/ lca2007.12.372.

32. Sheng, C., \& Azevedo, J.L.T. (2005). Estimating the higher heating value of biomass fuels from basic analysis data. Biomass and Bioenergy, 28(5), 499 - 507. DOI: 10.1016/j.biombioe.2004.11.008.

33. Vogel, E., Deumlich, D., \& Kaupenjohann, M. (2016). Bioenergy maize and soil erosion-Risk assessment and erosion control concepts. Geoderma, 261, 80 - 92. DOI: 10.1016/j.geoderma.2015.06.020.

34. Wischmeier, W.H., \& Smith, D.D. (1978). Predicting rainfall erosion losses-a guide to conservation planning. Hyattsville, Maryland, USA: Science and Education Administration. 